\title{
Electrospray ionization mass spectrometry fingerprinting of propolis of native Brazilian stingless bees*
}

\author{
Alexandra Christine Helena Frankland SAWAYA ${ }^{\mathrm{a}}$, Ildenize Barbosa da Silva CunHA ${ }^{\mathrm{b}}$, \\ Maria Cristina MARCUCCI ${ }^{\mathrm{c}}$, Davi Said AIDAR ${ }^{\mathrm{d}}$, Etelvina Conceição Almeida SILVA ${ }^{\mathrm{e}}$, \\ Carlos Alfredo Lopes CARvalHo ${ }^{\mathrm{f}}$, Marcos Nogueira EBERLIN ${ }^{\mathrm{a}}$
a ThoMSon Mass Spectrometry Laboratory, Institute of Chemistry, State University of Campinas, UNICAMP, Campinas, SP 13083-970, Brazil
${ }^{\text {b }}$ São Francisco University, USF, Bragança Paulista, SP, Brazil
${ }^{c}$ Bandeirante University of São Paulo, UNIBAN, CEP 02071-013 São Paulo, SP, Brazil
${ }^{\mathrm{d}}$ College of Agricultural Sciences, Federal University of Amazonas, CEP 69077-000 Manaus, AM, Brazil
${ }^{e}$ ETRON Apiary, km 13 Rodovia Ilhéus/Itabuna, (Ba 415) Ilhéus, BA, Brazil
${ }^{\mathrm{f}}$ Federal University of Recôncavo of Bahia (UFRB), 44380-000 Cruz das Almas, BA, Brazil

Received 11 April 2006 - Revised 23 June 2006 - Accepted 26 June 2006

\begin{abstract}
Stingless bees are found in many tropical and subtropical regions of the word. The knowledge of the composition of their propolis as well as the plants that are visited as sources of resins is therefore of prime importance. Here the negative ion mode electrospray ionization mass spectrometry [ESI(-)-MS] fingerprints of propolis from various species of native stingless bees from different regions in Brazil are compared to determine their composition patterns. The correlation among the propolis samples was investigated via chemometric analysis.
\end{abstract}

ESI-MS fingerprint / propolis / native stingless bees / Brazil

\section{INTRODUCTION}

Stingless bees (Hymenoptera, Apidae, Meliponini) are found in many tropical and subtropical regions of the word. They are the major visitors and native pollinators of flowering plants in the tropics, comprising a large group of small to medium sized bees with a level of social organization comparable to that of Apis mellifera bees (Heard, 1999). Native stingless bees are, however, less harmful to humans and domestic animals and resistant to the diseases and parasites of honeybees, and the propagation of their colonies contributes to the preservation of biodiversity (Aidar, 1996). Nevertheless, there

Corresponding author: A.C.H.F. Sawaya,

franksawaya@terra.com.br

* Manuscript editor: Stan Schneider is a poor level of domestication technology for most species of stingless bees (Heard, 1999). As their preferred nesting sites are the preformed cavities of live trees found mainly in primary forests, deforestation has decreased the density of these eusocial bees (Eltz et al., 2002). Therefore, information on the composition of the honey and propolis of these native bees, as well as the plants they visit as sources of pollen, nectar and resins, are of prime importance. Although studies have been performed on the overlap between native and introduced honey bees visiting flowers is several regions of Brazil (Wilms et al., 1996; Viana et al., 1997; Toledo et al., 2003), few studies have analyzed possible plant sources for the fabrication of propolis by stingless bees.

Bees collect exudates and resins from plants around their hives, adding wax to produce a 
complex mixture of variable chemical composition known as propolis. Bees use propolis to reinforce the combs and to keep the hive environment aseptic. A. mellifera propolis has been used by humans for many centuries for its multiple pharmacological properties (Marcucci, 1995), hence its chemical composition and plant sources have been studied for nearly a century. In contrast, the chemical composition of stingless bee propolis has only recently begun to be studied. Bankova et al. (1999) studied the essential oil content of propolis from three native stingless bees via gas chromatography mass spectrometry (GC/MS). Velikova et al. (2000a) studied the composition of ethanolic extracts of several samples of propolis from different species of native Brazilian stingless bees, concluding the chemical composition of the propolis samples analyzed was heterogeneous. Velikova et al. (2000b) isolated three ent-kaurene diterpenoids from a sample of Melipona quadrifasciata (M. quadrifasciata) propolis. Miorin et al. (2003) compared, by high performance liquid chromatography with a diode array detector (HPLC-DAD), the chemical composition of the ethanolic extracts of several samples of Tetragonisca angustula and A. mellifera propolis from the states of Paraná and Minas Gerais in Brazil, concluding that the composition $T$. angustula propolis differed from that of $A$. mellifera propolis from the same regions. Pereira et al. (2003) investigated by high temperature - high resolution gas chromatography with mass spectrometry (HT-HRGC/MS) the chemical composition of the dichloromethane, acetone and methanol extracts of one sample of propolis of A. mellifera and one sample of T. angustula from São Paulo, Brazil, concluding that the less polar (dichloromethane) extracts were identical, but the other extracts showed significant differences in composition. Pino et al. (2006) compared by GC/MS the volatile constituents of one sample of $A$. mellifera propolis and one sample of Melipona beecheii propolis from Mexico, concluding that although the flora in the region was similar, the composition of the two samples was different. In a recent study, we (Sawaya et al., 2006) used electrospray ionization mass spectrometry in the negative ion mode [ESI(-)-MS] to compare ethanolic extracts of ten samples T. angustula propolis from the south, southeast and northeast of Brazil and compared their ESI(-)-MS fingerprints to the fingerprints of plant extracts from these regions, concluding that the almost constant composition of $T$. angustula propolis in Brazil results from the collection of surface exudates from Schinus terebenthifolius as the preferred plant source. This plant, known locally as "aroeira vermelha" can be found throughout South America.

Mass spectrometry has been used in conjunction with gas chromatography (GC/MS) for many years for the analysis of the main volatile and semi-volatile components of propolis from A. mellifera bees, although many components are not volatile enough for direct GC/MS analysis. HT-HRGC-MS was used to analyze the hexane and acetone extracts of a sample of green Brazilian propolis (Pereira et al., 1998) while for the methanolic extracts, prior derivatization was necessary (Pereira et al., 2000).

ESI-MS has revolutionized the way molecules are ionized and transferred to mass spectrometers, greatly expanding the applicability of MS to non-volatile, thermally unstable, heavy and/or polar molecules. Therefore ESI-MS and its tandem version ESI-MS/MS with direct infusion (no previous separation) has been applied to the analysis of a variety of complex natural mixtures such as those found in plant extracts (Mauri and Pieta, 2000; Möller et al., 2007), beer (Araújo et al., 2005), vegetable oils (Catharino et al., 2005; Wu et al., 2004) wine (Catharino et al., 2006; Cooper and Marshal, 2001), whisky (Möller et al., 2005), and even the most complex chemical mixture: petroleum (Hughey et al., 2002).

ESI ionizes more efficiently polar compounds with acid (negative ion mode) or basic sites (positive ion mode) and the intensity of the ions observed in the ESI-MS fingerprints is affected by factors such as ionization conditions, $\mathrm{pH}$ of the solution used and matrix suppression (Cole, 1997). Although the method and sample matrix do not permit the visualization of all the compounds in the samples (as less polar to non-polar compounds do not ionize sufficiently) and the results are of a 
qualitative nature, one must bear in mind that it is not necessary to quantify all the compounds in a sample in order to characterize it. ESI(-)-MS fingerprinting focuses on the more polar and acidic components of the sample, which is of special importance for the study of propolis, as most of the pharmacologically active compounds so far identified in propolis are polar, frequently bearing acidic of phenolic sites (Marcucci et al., 1995). Therefore we have successfully applied ESI(-)-MS fingerprinting to typify propolis from different geographical regions, including the variable types of Brazilian propolis (Sawaya et al., 2004), and to compare propolis and plant extracts to determine the plant origins of the propolis samples (Marcucci et al., unpubl. data; Sawaya et al., 2006). These studies show, using standardized conditions (see material and methods), that different types of propolis display unique sets of polar and acid components hence that ESI(-)-MS fingerprinting can be used with confidence for propolis typification. In this study we compare the ESI(-)-MS fingerprints of ethanolic extracts of propolis of several species of native Brazilian stingless bees and some samples of $A$. mellifera propolis to determine patterns of composition for stingless bee propolis from different regions in Brazil. Furthermore, comparison with fingerprints of propolis samples with a known plant origin, permitted the identification of the plant origin of many of the propolis samples studied herein. To evaluate the correlation among the propolis samples, chemometric principal component analysis (PCA) was applied to the ESI(-)-MS data.

\section{MATERIALS AND METHODS}

\subsection{Propolis samples and extraction procedure}

Samples of propolis were provided by beekeepers from different regions in Brazil as summarized in Table I. All samples were frozen and ground prior to extraction. The samples were extracted by maceration for 7 days in a shaker, regulated at a speed of $100 \mathrm{opm}$ and temperature of $30^{\circ} \mathrm{C}$, with $10 \mathrm{~mL}$ of absolute ethanol (Merck, Darmstadt, Germany) for every $3 \mathrm{~g}$ of crude propolis. The insoluble portion was then separated by filtration, the filtrates kept in a freezer at $-16{ }^{\circ} \mathrm{C}$ overnight and filtered again at this temperature to reduce the wax content of the extracts. Solvent was then evaporated on a water bath at a temperature of $50{ }^{\circ} \mathrm{C}$ to obtain dry extracts of propolis.

\subsection{General experimental procedures}

The dry propolis extracts were dissolved in a solution of $70 \%(\mathrm{v} / \mathrm{v})$ chromatographic grade methanol (Tedia, Fairfield, OH, USA), 30\% (v/v) deionized water and $0.1 \%$ ammonium hydroxide. The solutions of propolis were infused directly into the ESI source by means of a syringe pump (Harvard Apparatus) at a flow rate of $10 \mu \mathrm{L}$ $\mathrm{min}^{-1}$. ESI(-)-MS and tandem ESI(-)-MS/MS were acquired using a hybrid high-resolution and highaccuracy $(5 \mu \mathrm{L} / \mathrm{L})$ Micromass Q-TOF mass spectrometer under the following conditions: capillary and cone voltages were set to $-3000 \mathrm{~V}$ and $-40 \mathrm{~V}$, respectively, with a de-solvation temperature of $100{ }^{\circ} \mathrm{C}$. For ESI(-)-MS/MS, the energy for the collision induced dissociations (CID) was optimized for each component. Diagnostic ions in the different propolis samples were identified by the comparison of their ESI(-)-MS/MS dissociation patterns with compounds identified in previous studies (Sawaya et al., 2004, 2006; Marcucci et al., unpubl. data). Although fingerprints were acquired in the $m / z 100-1000$ range, no important ions were observed below $\mathrm{m} / \mathrm{z}, 200$ or above $\mathrm{m} / \mathrm{z} 650$, therefore ESI(-)-MS data is shown in the $m / z, 200-650$ range.

\subsection{Chemometric analysis of data}

Principal Component Analysis (PCA) was performed using the 2.60 version of Pirouette software from Infometrix, Woodinville,WA, USA. The mass spectra were expressed as the intensities of individual $[\mathrm{M}-\mathrm{H}]^{-}$ions (i.e. variables) of the ten most intense ions in the fingerprints of each sample. The data was preprocessed using auto scale and the PCA method was run.

\section{RESULTS AND DISCUSSION}

ESI(-)-MS fingerprints were collected for each sample and the data was subject to 
Table I. Species of bee and place of origin of samples of propolis from Brazil.

\begin{tabular}{|c|c|c|c|}
\hline Sample & Species & Place of origin & Region \\
\hline Ta1 & Tetragonisca angustula & Claudio, Minas Gerais & Southeast \\
\hline $\mathrm{Ta} 2$ & Tetragonisca angustula & Florianópolis, Santa Catarina & South \\
\hline Ta3 & Tetragonisca angustula & Cruz das Almas, Bahia & Northeast \\
\hline Mq1 & Melipona quadrifasciata & Amazonas & North \\
\hline Mq2 & Melipona quadrifasciata & Amazonas & North \\
\hline Mq3 & Melipona quadrifasciata & Cruz das Almas, Bahia & Northeast \\
\hline $\mathrm{Mq} 4$ & Melipona quadrifasciata & Ribeirão Preto, São Paulo & Southeast \\
\hline Pr1 & Plebeia remota & Prudentopolis, Paraná & South \\
\hline $\operatorname{Pr} 2$ & Plebeia remota & Prudentopolis, Paraná & South \\
\hline $\operatorname{Pr} 3$ & Plebeia remota & Paraná & South \\
\hline $\mathrm{Pd}$ & Plebeia droryana & Atibaia, São Paulo & Southeast \\
\hline $\mathrm{Pd} 3$ & Plebeia droryana & Ubatuba, São Paulo & Southeast \\
\hline Ps1 & Plebeia sp. & Paraná & South \\
\hline Ps2 & Plebeia sp. & Itaparica, Bahia & Northeast \\
\hline Ls & Lestrimelitta spp. & Paraná & South \\
\hline $\mathrm{Tc}$ & Tetragona clavipes & Paraná & South \\
\hline $\mathrm{Nt}$ & Nannotrigona testaceicornis & Minas Gerais & Southeast \\
\hline $\mathrm{Sb}$ & Scaptotrigona bipunctata & Paraná & South \\
\hline Ms1 & Melipona scutellaris & Bahia & Northeast \\
\hline Ms2 & Melipona scutellaris & Cruz das Almas, Bahia & Northeast \\
\hline Ms3 & Melipona scutellaris & Sauipe, Bahia & Northeast \\
\hline Ms4 & Melipona scutellaris & Amazonas & North \\
\hline Mf & Melipona favosa & Corumbá, Mato Grosso do Sul & Midwest \\
\hline Am1 & Apis mellifera & Paraná & South \\
\hline Am2 & Apis mellifera & Bahia & Northeast \\
\hline Am3 & Apis mellifera & Cruz das Almas, Bahia & Northeast \\
\hline
\end{tabular}

chemometric analysis. Figure 1 shows the PCA analysis of the ESI(-)-MS fingerprints of all the samples of propolis from stingless bees and A. mellifera collected in Brazil. Due to characteristic sets of polar and/or acid components, the samples are clearly divided into three main groups (Fig. 1A) mainly due to several diagnostic ESI(-)-MS ions circled in Figure 1B. A detailed analysis of these ions allows us to indicate the main plant sources of these propolis samples (see below). To illustrate, Figure 2 shows ESI(-)-MS fingerprints of typical samples of each group.

Group 1 is composed of the following nine propolis samples: three of T. angustula (from the Santa Catarina, Minas Gerais and Bahia); one of Nannotrigona testaceicornis from Mi- nas Gerais; one of Plebeia sp. from Itaparica, Bahia; one of Plebeia droryana (P. droryana) from São Paulo; and the three remaining samples were from Cruz das Almas, Bahia, that is one of A. mellifera, one of Melipona scutellaris (M. scutellaris) and one of M. quadrifasciata. Figure 2 shows, as characteristic examples of Group 1, a fingerprint of $T$. angustula propolis from Minas Gerais (Fig. 2A) and a fingerprint of $P$. droryana from São Paulo (Fig. 2B). In a previous study (Sawaya et al., 2006), samples of T. angustula propolis from different regions Brazil were found to have the ions of $m / z, 371,373,401,453,455$, 469 and 471, that are diagnostic for samples of propolis derived from $S$. terebenthifolius resins. The samples of propolis belonging to 

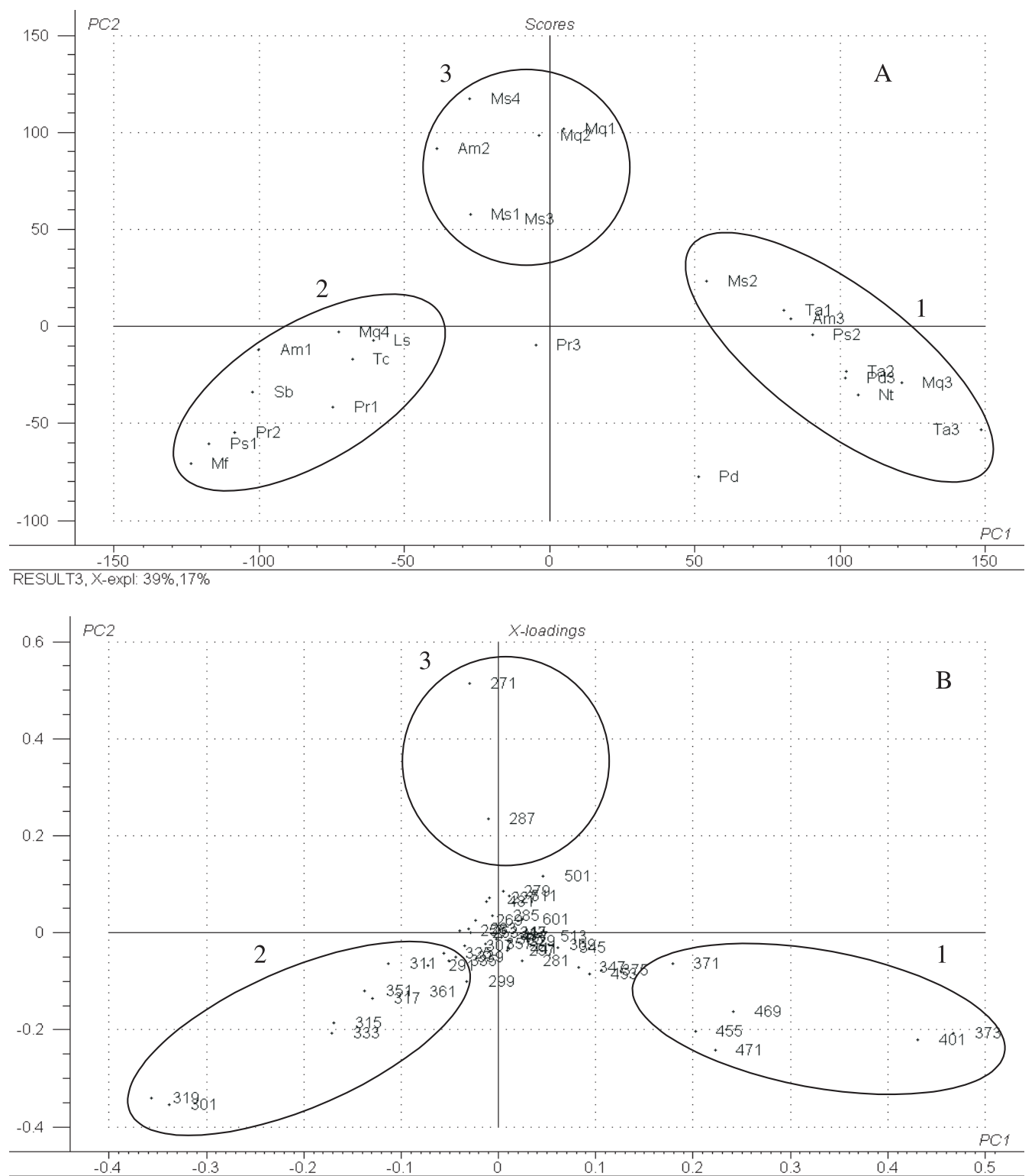

RESULT3, X-expl: 39\%,17\%

Figure 1. PCA analysis of the ESI(-)-MS fingerprint data for the extracts of A. mellifera and native Brazilian stingless bee propolis from the south, southeast, midwest, north and northeast of Brazil (for species see Tab. 1): (A) grouped samples and (B) characteristic ions for each group. Ions circled in (B) are those most characteristic (diagnostic) for each group whereas those more in the center are common to many samples. 


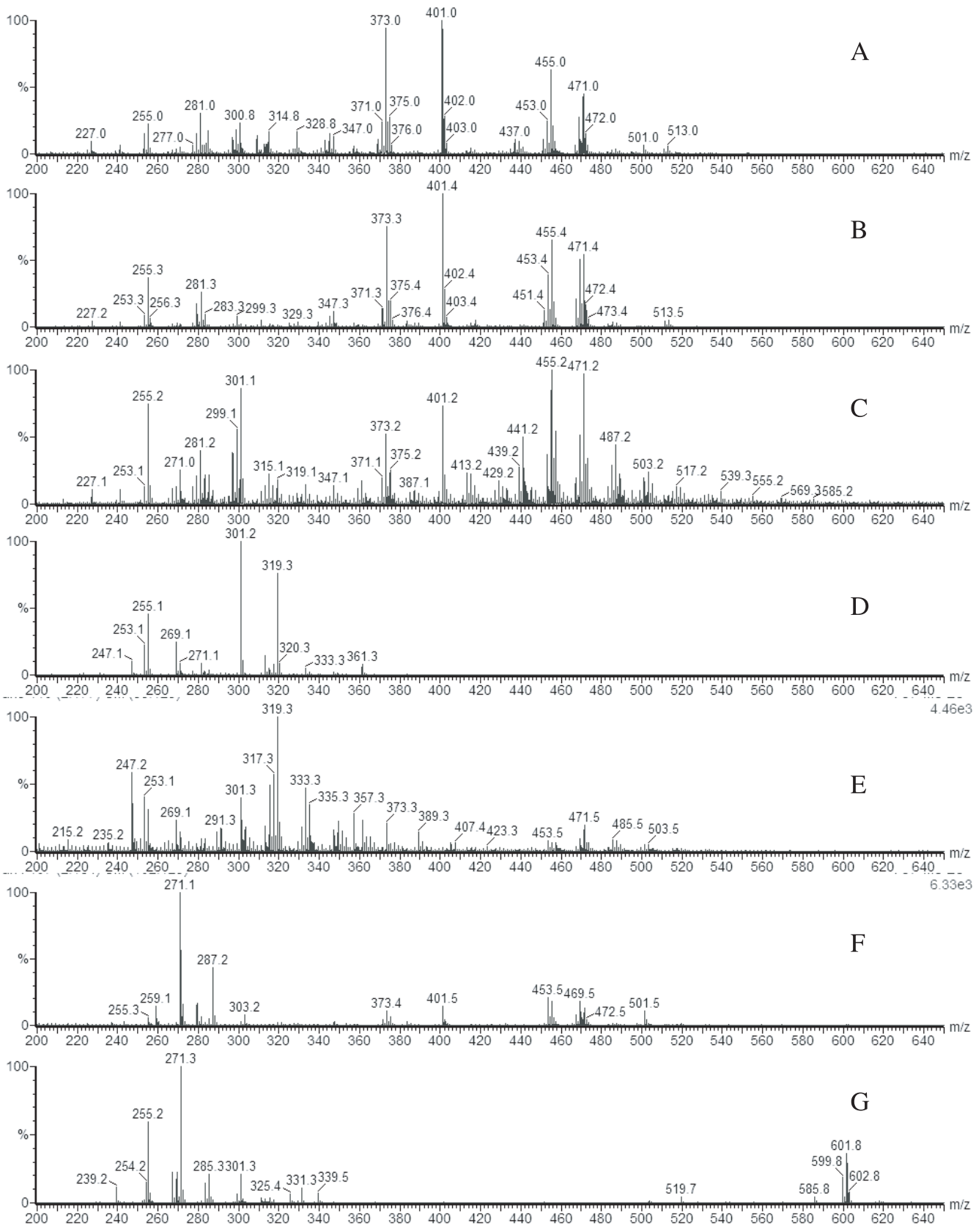

Figure 2. ESI(-)-MS fingerprints of propolis, origin and type: (A) T. angustula from Minas Gerais Group 1; (B) P. droryana from Sao Paulo - Group 1; (C) P. droryana from Sao Paulo - intermediate Groups 1 and 2; (D) A. mellifera from Paraná - Group 2; (E) P. remota from Paraná - Group 2; (F) M. quadrifasciata from Amazonas - Group 3 and $(\mathrm{G})$ A. mellifera from Bahia - Group 3. 
Group 1 contain these same diagnostic ions (Fig. 1B), indicating that they derive their resins mainly from $S$. terebenthifolius, a tree 2-6 m high, belonging to the Anacardiaceae family, known in Brazil as "aroeira vermelha". The leaves and fruit of $S$. terebenthifolius are popularly used for medicinal purposes and contain substances with known medicinal properties (Jain et al., 1995; Schmourlo et al., 2005). References have been found to several species of native bees visiting this plant in the state of São Paulo (Ramalho et al., 1990) and in the south of Brazil (Wilms et al., 1997). Due to the wide geographic distribution of S. terebenhtifolius, it is hardly surprising that propolis samples from different regions (south, southeast and northeast of Brazil) use this plant source. The samples of T. angustula propolis analyzed in the present study were not the same ones analyzed in the previous paper (Sawaya et al., 2006), which reinforces our findings that $S$. terebenhtifolius is a major resin source for T. angustula.

Group 2 is also composed of 9 propolis samples: two of Plebeia remota ( $P$. remota), one of Plebeia sp., one of Lestrimelitta sp., one of Tetragona clavipes, one of Scaptotrigona bipunctata ( $S$. bipunctata) and one of A. mellifera from Paraná; one of Melipona favosa from Mato Grosso do Sul and one of M. quadrifasciata from São Paulo. Figure 2D shows a fingerprint of $A$. mellifera propolis from Paraná whereas Figure 2E shows that of $P$. remota from Paraná, both characteristic fingerprints of group 2. The ions of $m / z 301,315$, $317,319,333$, and 361 that are the most diagnostic for these samples (Fig. 1B), which are characteristic of brown A. mellifera propolis from the south of Brazil. These ions are also found in resins of Araucaria pine trees and were characterized by comparison of their ESI-MS/MS (Marcucci et al., unpubl. data). Most of the samples of Group 2 come from the state of Paraná, where Araucaria trees are common and these resins are apparently the main source of propolis for bees in the south of Brazil. Furthermore, ions of $\mathrm{m} / z, 253,255$ and 269 found in the fingerprints of both samples of propolis (Fig. 2D-E) are also characteristic of brown propolis from the south of Brazil and were identified by ESI-MS/MS as flavonoids commonly found in poplar type propolis in Europe (Sawaya et al., 2004). Although the plant source for these flavonoids in southern Brazil has not been determined yet it is noteworthy that both native ( $P$. remota) and introduced (A. mellifera) bees take resins from this source. The sample of $P$. remota propolis from the south of Brazil (Fig. 2E) also contains compounds derived from $S$. terebenthifolius, as revealed by the detection of ions of $m / z 453$ and 471 in the ESI(-)-MS fingerprint, albeit with low intensity. Due to matrix suppression, one cannot affirm that the intensity of an ion is proportional to its concentration.

Two samples of propolis ( $P$. droryana from São Paulo and $P$. remota from Paraná) were placed between Groups 1 and 2 in the PCA analysis (Fig. 1A), which indicates that both $S$. terebenthifolius and Araucaria were used as plant sources. Figure $2 \mathrm{C}$ shows the fingerprint of such a sample $(P$. droryana propolis from São Paulo) where the ions of $m / z 301$ and 319 (characteristic of Araucaria) as well as $m / z$ 373, 401, 455 and 471 (characteristic of $S$. terebenthifolius) are observed.

Group 3 is composed of the following six propolis samples: two of $M$. scutellaris from Bahia and one of M. scutellaris from Amazonas; two of M. quadrifasciata from Amazonas and one of A. mellifera from Bahia. By far the major diagnostic ion responsible for grouping these samples is that of $\mathrm{m} / \mathrm{z} 271$ (Fig. 1B), and this ion is very characteristic for the ruby $\operatorname{red} A$.mellifera propolis from the northeast of Brazil (Sawaya et al., 2004). Although the plant source of this type of propolis has not been determined yet, it is apparently a plant source for propolis of several species of bees in the tropical region of Brazil. Figure 2F shows the ESI(-)-MS fingerprint of ruby red $A$. mellifera propolis from Bahia. The ion of $m / z, 601$ is characteristic of ruby red propolis from the coastal regions of the state of Bahia and was observed with less intensity in several samples of stingless bee propolis from this state (data not shown). Figure $2 \mathrm{G}$ shows a fingerprint of $M$. quadrifasciata propolis from Amazonas where the ion of $m / z 271$ is the most intense, but less intense ions which are characteristic of $S$. terebenthifolius $(\mathrm{m} / \mathrm{z} 373,401,453$ and 469) are also 


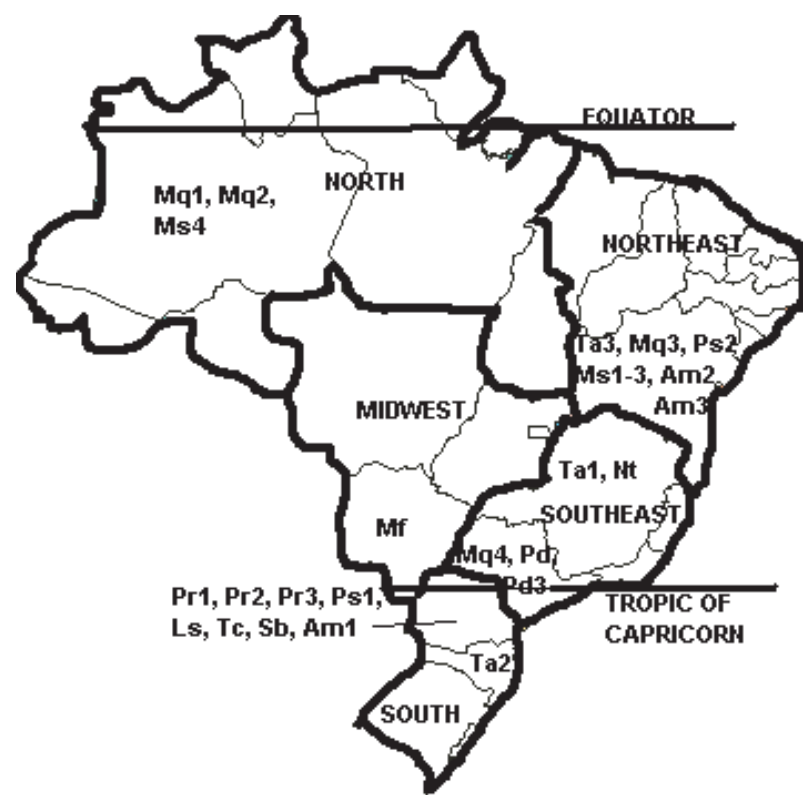

Figure 3. Map of Brazil indicating the geographic origin of the propolis samples. Sample names abbreviated as in Table I.

observed. Both fingerprints are characteristic of Group 3 samples.

Most of ESI(-)-MS fingerprints of the samples of propolis from native Brazilian stingless bees contained ions characteristic of $S$. terebenthifolius, whereas only three of the samples analyzed contained no trace of these ions (two samples of $M$. scutellaris from Bahia and Amazonas, and one of S. bipunctata from Paraná). This finding is consistent with reports in which numerous stingless bees were found visiting S. terebenthifolius flowers (Ramalho et al., 1990; Wilms et al., 1997). These results indicate that $S$. terebenthifolius is an important plant source for propolis of native Brazilian stingless bees. In regions where other plant sources are present, stingless bees can adapt and use different plants (such as Araucaria in the southern regions of Brazil).

A map of Brazil indicating the states and regions in which the samples of propolis were collected can be seen in Figure 3. Most of the samples were collected in tropical regions, with a wide variety of vegetation. The samples collected in the south of Brazil, states of Paraná and Santa Catarina, show the influence of the vegetation, with Araucaria trees being an important plant source for these samples. In the southeast of Brazil, A. mellifera bees use Baccharis dracunculifoia, as the main plant source for propolis, resulting in the world famous green Brazilian propolis (Bankova et al., 1999; Marcucci et al., unpubl. data). Diagnostic ions of the prenylated phenolic compounds found in green $A$. mellifera propolis (Sawaya et al., 2004) were not found in any of the fingerprints of native stingless bees, in spite of containing both acid and phenolic sites and ionizing well in the negative mode. Therefore we observed that, even in the southeast of Brazil where this shrub is common, native bees do not use B. dracunculifoia as a plant source for their propolis.

\section{CONCLUSIONS}

ESI(-)-MS fingerprints of the samples of native Brazilian stingless bee propolis allow us to conclude that $S$. terebenthifolius is an important plant source for these stingless bees. The diagnostic ions of $S$. terebenthifolius resins, those of $m / z 371,373,401,453,455$, 
469 and 471, are the most intense in the fingerprints of all the samples of $T$. angustula and $N$. testaceicornis analyzed. These ions are also present in all the samples of propolis from the species of Plebeia analyzed, and in several samples of the other stingless bee species (eg. Fig. 2F). Stingless bees can however use many of the same plant sources as A. mellifera; in the fingerprints of samples of stingless bee propolis from the south of Brazil, the characteristic ions of Araucaria resins $(\mathrm{m} / \mathrm{z} 301,319)$ and some flavonoids ( $m / \mathrm{z} 253,255$ and 269) are observed that are common in A. mellifera propolis from this area. What is more surprising, is that sometimes native bees seem to simply ignore a potential plant source used by $A$. mellifera. For example, none of the characteristic ions of green A. mellifera propolis are observed in the fingerprints of any of the samples of stingless bee propolis from the southeast of Brazil, indicating that Baccharis dracunculifolia was not used as a source of resins by any of the stingless bees studied.

\section{ACKNOWLEDGEMENTS}

This work has been supported by the São Paulo State Research Foundation (FAPESP) and the Brazilian National Research Council (CNPq).

Spectrométrie de masse par ionisation avec électronébulisation, une méthode par fingerprint pour caractériser la propolis des abeilles sans aiguillon indigènes du Brésil.

propolis / spectrométrie de masse par ionization avec électronébulisation / abeille sans aiguillon / Apidae / Meliponini / Brésil / Schinus therebentifolius

Zusammenfassung - Elektrospray-IonisationsMassenspektrometrie, eine Methode zur Fingerabdruckanalyse von Propolis brasilianischer Stachelloser Bienen. Stachellose Bienen kommen in vielen tropischen und subtropischen Regionen der Welt vor und sind in diesen Regionen wichtige Bestäuber. Nichtsdestotrotz ist die Haltungstechnologie für die meisten Arten Stachelloser Bienen noch auf einem relativ niedrigen Niveau. Obwohl für Brasilien bereits verschiedene Studien zur Nischenüberlappung von einheimischen Bienen mit den eingeführten Honigbienen vorliegen, gibt es nur wenig Informationen zu Pflanzen, die von Stachellosen Bienen als Harzquelle für die Herstellung von Propolis genutzt werden. Propolisproben, die von Imkern in verschiedenen Regionen Brasiliens gewonnen wurden (zusammengestellt in Tab. 1), wurden eingefroren und für die Extraktion zermahlen. Die mazerierten Proben wurden auf einem Schüttler während sieben Tagen in Alkohol extrahiert und anschliessend im negativen Ionenmodus per Elektrospray-Ionisations-Massenspektrometrie [ESI(-)-MS] in einem Q-TOF-Massenspektrometer (Micromass) analysiert. Mittels einer chemometrischen Hauptkomponentenanalyse (PCA) wurden statistisch signifikante Korrelationen in diesen Fingerabdrucksanalysen der Propolisproben aufgedeckt. Abbildung 1 zeigt die PCA-Ergebnisse der ESI(-)-MS Fingerabdrücke von Propolisproben Stachelloser Bienen und von Honigbienen. Die Proben teilen sich anhand ihrer charakteristischen Ionen klar in drei Gruppen auf (Abb. 1A, B). Abbildung 2 zeigt ESI(-)-MS-Spektren typischer Proben aus jeder dieser Gruppen. Gruppe 1 besteht aus neun Propolisproben, für die die Ionen $m / z, 371,373,401$, 453, 455, 469 und 471 für die Gruppierung verantwortlich sind. Diese Ionen sind charakteristisch für Tetragonisca angustula Propolis, die diese Bienen in ganz Brasilien überwiegend von Schinus terebenthifolius sammeln. Gruppe 2 besteht ebenfalls aus neun Propolisproben, mit den Gruppierungsionen $m / z$ 301, 315, 317, 319, 333, and 361. Diese sind für die braune $A$. mellifera Propolis charakteristisch, die vor allem aus Südbrasilien stammt und in der die Bienen Harze der Araucaria Tanne verarbeiten. Zwei Propolisproben ( $P$. droryana aus São Paulo und $P$. remota aus Paraná) lagen zwischen diesen beiden Gruppen (Abb. 1A), was darauf hinweist, dass diese Bienen sowohl S. terebenthifolius als auch Araucaria Harze sammelten. Gruppe 3 besteht aus sechs Propolisproben, für die das Hauption $(m / z, 271)$ für die Gruppierung verantwortlich zeigt. Dieses ist charakteristisch für rote Robinienpropolis von A. mellifera aus dem Nordosten Brasiliens. Die meisten Fingerabdrücke von Propolisproben der einheimischen Stachellosen Bienen zeigten die für $S$. terebenthifolius charakteristischen Ionen. Diese in ganz Brasilien vorkommende Pflanze enthält medizinisch wirksame Substanzen und wird häufig von Stachellosen Bienen besucht. Unsere Ergebnisse zeigen, dass S. terebenthifolius eine wichtige Quelle für die Propolisgewinnung darstellt, dass Stachellose Bienen aber auch andere Pflanzen, insbesondere Aurakarien nutzen können.

ESI-MS Fingerabdruck / Propolis / Stachellose Bienen / Brazil

\section{REFERENCES}

Aidar D.S. (1996) A Mandaçaia: Manejo e multiplicação de colônias de Melipona quadrifasciata. Séries monográficas 4, Braz. J. Genet., 103 p. 
Araújo A.S., Rocha L.L., Tomazela D.M., Sawaya A.C.H.F., Almeida R.R., Catharino R.R., Eberlin M.N. (2005) Electrospray ionization mass spectrometry fingerprinting of beer, Analyst 130, 884-889.

Bankova V., Boudorova-Krasteva G., Sforcin J., Frete X., Kujumjiev A., Maimoni-Rodella R., Popov S. (1999) Phytochemical Evidence for the Plant Origin of Brazilian Propolis from São Paulo State, Z. Naturforsch. 54 c, 401-405.

Catharino R.R., Hadad R., Cabrini L.G., Cunha I.B.S., Sawaya A.C.H.F., Eberlin M.N. (2005) Characterization of Vegetable Oils by Electrospray Ionization Mass Spectrometry Fingerprinting: Classification, Adulteration and Aging, Anal. Chem. 77, 7429-7433.

Catharino R.R., Cunha I.B.S., Fogaça A.O., Facco E.M.P., Godoy H.T., Daudt C.E., Eberlin M.N., Sawaya A.C.H.F. (2006) Characterization of must and wine of six varieties of grapes by direct infusion electrospray ionization mass spectrometry, J. Mass Spectrom. 41, 185-190.

Cole R.B. (1997) Electrospray Ionization Mass Spectrometry, John Wiley and Sons Inc., New York.

Cooper H.J., Marshal A.G. (2001) Electrospray ionization Fourier transform mass spectrometric analysis of wine, J. Agr. Food Chem. 49, 5710-5718.

Eltz T., Brühl C.A., Kaars S., Linsenmair K.E. (2002) Determinants of stingless bee density in lowland dipterocarp forests of Sabah, Malaysia, Oecologia $131,27-34$.

Heard T.A. (1999) The role of stingless bees in crop pollination, Annu. Rev. Entomol. 44, 183-206.

Hughey C.A., Rodgers R.P., Marshall A.G. (2002) Identification of acidic NOS compunds in crude oils in different geochemical origins by negative ion electrospray Fourier transform íon cyclotron resonance mass spectrometry, Org. Geochem. 33, $743-759$

Jain M.K., Yu B., Rodgers J.M., Smith A.E., Boger E.T.A., Ostander R.L., Rheingold L. (1995) Specific competitive inhibitor of secreted Phospholipase $\mathrm{A}_{2}$ from berries of Schinus terebenthifolius, Phytochemistry 39, 537-547.

Marcucci M.C. (1995) Propolis: Chemical composition, biological properties and therapeutic activity, Apidologie 26, 83-99.

Mauri P., Pietta P. (2000) Electrospray characterization of selected medicinal plant extracts, J. Pharm. Biomed. Anal. 23, 61-68.
Miorin P.L., Levy Jr. N.C., Custodio A.R., Bretz W.A., Marcucci M.C. (2003) Antibacterial activity of honey and propolis from Apis mellifera and Tetragonisca angustula against Staphylococcus aureus, J. Appl. Microbiol. 95, 913-920.

Möller J.K.S., Catharino R.R., Eberlin M.N. (2005) Electrospray ionization mass spectrometry fingerprinting of whisky: immediate proof of origin and authenticity, Analyst 130, 890-897.

Möller J.K.S., Skibstead L.H., Catharino R.R., Eberlin M.N. (2007) Electrospray ionization mass spectrometry fingerprinting of essential oils: Spices from the Labiatae family, Food Chem. 100, $1283-1288$

Pereira A.S., Pinto A.C., Cardoso J.N., Aquino Neto F.R., Ramos M.F.S., Dellamora-Ortiz G.M., Santos E.P. (1998) Application of High Temperature High Resolution Gas Chromatography to Crude Extracts of Propolis, J. High Resol. Chromatogr. 21, 396-400.

Pereira A.S., Norsell M., Cardoso J.N., Aquino Neto F.R. (2000) Rapid screening of polar compounds in Brazilian propolis by high-temperature highresolution gas chromatography-mass spectrometry, J. Agr. Food Chem. 48, 5226-5230.

Pereira A.S., Bicalho B., Aquino Neto F.R. (2003) Comparison of propolis from Apis mellifera and Tetragonisca angustula, Apidologie 34, 291-298.

Pino J.A., Marbot R., Delgado A., Zumárraga C., Sauri E. (2006) Volatile Constituents of Propolis from Honey Bees and Stingless Bees from Yucatán, J. Essent. Oil Res. 18, 53-56.

Ramalho M., Kleinert-Giovannini A., ImperatrizFonseca V.L. (1990) Important bee plants for stingless bees (Melipona and Trigonini) and Africanized honeybees (Apis mellifera) in neotropical habitats: a review, Apidologie 21, $469-488$.

Sawaya A.C.H.F., Tomazela D.M., Cunha I.B.S., Bankova V.S., Marcucci M.C., Custodio A.R., Eberlin M.N. (2004) Electrospray ionization mass spectrometry fingerprinting of propolis, Analyst $129,739-744$.

Sawaya A.C.H.F., Cunha I.B.S., Marcucci M.C., Rodrigues R.F.O., Eberlin M.N. (2006) Brazilian Propolis of Tetragonisca angustula and Apis mellifera, Apidologie 37, 398-407.

Schmourlo G., Mendonça-Filho R.R., Alviano C.S., Costa S.S. (2005) Screening of antifungal agents using ethanol precipitation and bioautography of medicinal and food plants, J. Ethnopharm. 96, $563-568$. 
Toledo V.A.A., Fritzen A.E.T., Neves C.A., RuvoloTakasusuki M.C.C., Sofia S.H., Terada Y. (2003) Plants and Pollinating Bees in Maringá, State of Paraná, Brazil, Braz. Archiv. Biol. Technol. 46, 705-710.

Velikova M., Bankova V., Marcucci M.C., Tsvetkova I., Kujumgiev A. (2000a) Chemical Composition and Biological Activity from Brazilian Meliponinae, Z. Naturforsch. 55c, 785-789.

Velikova M., Bankova V., Tsvetkova I., Kujumgiev A. Marcucci M.C. (2000b) Antibacterial ent-kaurene from Brazilian propolis of native stingless bees, Fitoterapia 71, 693-696.

Viana B.F., Kleinert A.M.P., Imperatriz-Fonseca V.L. (1997) Abundance and Flower Visits in a Serrado of Bahia, Tropical Brazil, Stud. Neotrop. Fauna E. $32,212-219$.
Wilms W., Imperatriz-Fonseca V.L., Engels W. (1996) Resource Partitioning between Highly Eusocial Bees and Possible Impact of the Introduced Africanized Honey Bee on Native Stingless Bees in the Brazilian Atlantic Rainforest, Stud. Neotrop. Fauna E. 31, 137-151.

Wilms W., Wendel L., Zillikens A., Blochstein B., Engels W. (1997) Bees and other insects recorded on flowering trees in a subtropical Araucaria forest in southern Brazil, Stud. Neotrop. Fauna E. 32, 220-226.

Wu Z., Rodgers R.P., Marshall A.G. (2004) Characterization of vegetable oils: Detailed compositional fingerprints derived from electrospray ionization Fourrier transform ion cyclotron ressonance mass spectrometry, J. Agr. Food Chem. 52, 5322-5328. 